\title{
Microrefuge exploitation by subtidal encrusting sponges: patterns of settlement and post-settlement survival
}

\author{
Manuel Maldonado*, María J. Uriz \\ Department of Aquatic Ecology, Centro de Estudios Avanzados de Blanes (CSIC), Camino de Santa Barbara s/n, \\ E-17300 Blanes, Girona, Spain
}

\begin{abstract}
The larvae of many sessile marine invertebrates are able to locate and settle selectively in physical microrefuges where the survival of the post-larval stage may be enhanced. However, it has been suggested that clonal encrusting organisms with unlimited attachment to the substratum do not rely heavily on microrefuges for post-larval survival, since they quickly outgrow refuges and then suffer partial rather than total mortality. Consequently, the larva of such organisms is predicted to show little selectivity at the time of settlement. This prediction, verified for some bryozoans and ascidians, has also been extrapolated to sponges despite the fact that there is virtually no field information on patterns of settlement and post-settlement mortality in this group. In the present study, we investigated patterns of settlement and juvenile mortality in 2 common Mediterranean encrusting sponges, Crambe crambe and Scopalina lophyropoda. We placed a set of grooved plates (providing microrefuges for larval settlement) and a set of smooth plates (without refuges) in the natural community, mapped larval settlement on plates at $3 \mathrm{~d}$ intervals, and recorded the fate of each settled larva for $10 \mathrm{wk}$. The total number of larvae of $C$. crambe that settled on the plates was significantly higher than that of $S$ lophyropoda, and both species settled preferentially in the microrefuges of the grooved plates. On each of the grooved plates, larvae settled preferentially on the shaded sides of outer ridges, avoiding equivalent ridge sides that were highly exposed to light. This pattern suggests that microrefuges are located by larvae on the basis of photic cues. The analysis of survival time revealed that survival of post-larval stages protected in grooves was higher in both species compared to unprotected post-larvae. The survival curve of the juveniles did not clearly follow an exponential model. Survival decreased more or less rapidly for the first 2 mo, but the chance of mortality was not markedly higher 1 wk after settlement than during subsequent weeks. Because we could not exert control over the various coincidental mortality factors that affected the sponges settled on the experimental plates, we tested the following hypotheses in the laboratory: (1) that the abundant echinoderms inhabiting these assemblages cause significant mortality by both unselective ingestion and abrasion, and (2) that microrefuges substantially reduce sponge vulnerability to this mortality factor. In this experiment, we investigated differences in mortality among small sponges as a function of microhabitat exploitation (sponges protected in grooves versus unprotected sponges on smooth surfaces) and the presence/absence of potential predators (the sea urchin Paracentrotus lividus, the starfish Echinaster sepositus). It was found that $E$. sepositus caused negligible mortality, irrespective of sponge microhabitat. In contrast, $P$. Lividus caused significant mortality, indicating that bulldozing by urchins may have substantial negative effects on sponge recruitment in temperate hard-bottom communities where urchins are ubiquitous. Our results also indicate that exploitation of physical microrefuges, such as grooves and crevices, reduces, but does not prevent, sponge mortality due to bulldozing by urchins. The enhancement of juvenile survival in microrefuges has probably operated as a selective force, favoring larval mechanisms that facilitate selective settlement in refuges.
\end{abstract}

KEY WORDS: Settlement choice - Juvenile mortality - Recruitment Microhabitat exploitation . Survivorship Parenchymella larva Larval ecology Sponges

\section{INTRODUCTION}

Active substratum exploration by marine invertebrate larvae at the time of settlement is a well-docu- mented event. The discriminatory ability of the larva is thought to facilitate settlement in suitable sites that often consist of physical refuges (crevices, pits, downward facing surfaces, etc.) where the juveniles are less 
exposed to predators, UV radiation, silt, autotrophic competitors, and other deleterious factors (Keough \& Downes 1982, Young \& Chia 1984, Chabot \& Bourget 1988, Barry \& Dayton 1991, Walters 1992, Hurlbut 1993, Wulff 1995)

Theoretically, selective settlement in microrefuges is expected only in larvae with sensory receptors and a system to translate and transfer the information perceived to organs capable of effecting behavioral responses. Despite the fact that sensory organs and/or nervous integration remain unknown in Porifera, it has traditionally been thought that sponge larvae use both gravity and light stimuli for orientation during dispersal and settlement (Fell 1974, 1989, and references therein). Recent studies have shown, however, a reduction in the buoyancy of the sponge larva with increasing age (Maldonado et al. 1997). Because this mechanism plays an important role in passively moving late-stage larvae towards the bottom when the time of settlement approaches, it is unlikely that larvae are capable of an active geotactic response. Rather, it appears that the behavioral spectrum of the sponge larva is limited to a photoresponse. The idea that photoreception takes place in Porifera is supported by many behavioral observations, but also by recent findings reporting the presence of proteins in sponges that are consistently involved in the processes of photoreception and vision in other animal phyla (Krasko et al. 1997). Some behavioral observations strongly suggest that larval photoreception occurs in the epithelial regions of the posterior end of the larva (Woollacott 1993, Maldonado \& Young 1996)

The negative phototaxis shown by larvae of many shallow-water sponges is thought to facilitate settlement in refuges (crevices, pits, undersides, etc.), where juvenile survival may be enhanced (Bergquist et al. 1970, Uriz 1982, Maldonado \& Young 1996, Lindquist et al. 1997). However, this point remains speculative. There are many references to the behavior of sponge larvae in the laboratory and about how this behavior might explain the spatial distribution of the adults, but very few attempts have been made to test this hypothesis in the field and the little literature available provides controversial results. Some authors have reported the absence of correlation between larval photobehavior and the field distribution of several sponges (i.e. McDougall 1943, Amano 1986, Maldonado \& Young 1996). Furthermore, some sponge species, the larvae of which are negatively phototactic, are significantly more abundant in sites exposed to light than in shaded sites in the field. This conflict has been tentatively explained by suggesting that, although adult sponges are clearly exposed to light, their original settlement sites may actually have been located in small crevices or holes, where the juveniles were pro- tected (Maldonado \& Young 1996). In contrast, Bergquist et al. (1970) reported for the first time a significant correlation between the larval photoresponses in the laboratory and the adult distributions in the field. However, these authors did not make any attempt to estimate settlement or short-term recrujtment in shaded versus light-exposed sites. Consequently the extent to which the observed pattern was a result of selective mortality following unselective settlement remains unclear.

Our present knowledge on the ecology of early lifehistory stages of sponges is so deficient that one can neither support nor reject the hypotheses (1) that active selection of refuges for settlement rather than unselective settlement is the pattern in the field, and (2) that the probability of juvenile survival is increased in settlement sites selected by the larvae. This latter issue is extremely relevant because for selective settlement to be adaptive, juvenile mortality must be reduced in preferred settlement sites (Hurlburt 1993). Most of the little knowledge on juvenile mortality in sponges comes from studies on tropical sponges and cannot easily be extrapolated to other areas, because the sources of juvenile mortality may vary locally, and consequently so may the effectiveness of refuges. For example, in the western Mediterranean assemblages where the present study was carried out, catastrophic mortality of juvenile sponges by natural episodic events (e.g. hurricanes) may be negligible compared to tropical areas (Wulff 1995). On the other hand, some generalist grazers that are ubiquitous in many temperate subtidal communities, such as sea urchins, may have significant effects on sponge recruitment (Ayling 1980, 1981). The destructive effect of urchins on the benthic community is known as 'bulldozing' (Gosselin \& Qian 1997) because it results from a combination of ingestion by grazing and abrasion by crawling. The sea urchin Paracentrotus lividus occurs at relatively high densities in most littoral Mediterranean assemblages (Ballesteros 1987, Turon et al. 1995), and it performs considerable nocturnal movements (Shepherd \& Bouderesque 1979, Dance 1987). Therefore, this herbivorous urchin may potentially cause significant mortality among juvenile sponges by both abrasion as it forages and unselective ingestion (Nédeléc 1982). Similarly, the common asteroid Echinaster sepositus may also have some effect on sponge recruitment, since it is basically a sponge-feeder (Vasserot 1961, Sará \& Vacelet 1973, Garcia-Raso et al. 1992). However, neither the effects of these abundant echinoderms as potential sources of mortality among juvenile sponges nor the potential role of physical microrefuges in reducing this mortality has ever been investigated in Mediterranean subLittoral communities. 
It has been predicted from studies on ascidians and bryozoans that clonal encrusting organisms with unlimited attachment to the substratum do not rely heavily on microrefuges for post-larval survival, since they quickly outgrow refuges and then suffer partial rather than total mortality (Jackson 1977, Jackson \& Hughes 1985, Dayton 1989, Walters \& Wethey 1996). Consequently, the larva of such organisms has also been predicted to show little selectivity at the time of settlement (Walters \& Wethey 1996). These predictions have been extrapolated to sponges, despite the fact that virtually no field information on the selectiveness of settlement or post-settlement mortality is available in the phylum Porifera. In the present study, we used 2 common encrusting sponges, Crambe crambe (Schmidt) and Scopalina lophyropoda Schmidt, to test for the first time in Porifera the hypotheses (1) that sponge larvae settle selectively in microrefuges in the field, (2) that refuges are basically selected on the basis of photic cues, and (3) that microrefuges reduce sponge vulnerability to predators and, in general, enhance the survival of early post-settlement stages.

\section{MATERIAL AND METHODS}

Study site and sponge species. The field study was conducted in a community of hemisciaphilic algae established on the north-facing, vertical sides of several submerged outcrops close to the Blanes coastline $\left(2^{\circ} 48.12^{\prime} \mathrm{N}, 41^{\circ} 40.33^{\prime} \mathrm{E}\right.$, Spain, Western Mediterranean). We knew from previous studies in this community (1) that the 2 sponges studied, Crambe crambe and Scopalina lophyropoda (hereafter Crambe and Scopalina) are the dominant invertebrates in terms of surface cover (Becerro et al. 1994, Turon et al. 1996), (2) that larval release is coincidental in the 2 sponges from late July to early September (Uriz et al. 1988), (3) that the larvae of both species are negatively phototactic at the time of settlement (Uriz 1982, authors' unpubl.), and (4) that both swimming and newly settled larvae of either species can be identified in situ on the basis of their color (orange in Scopalina versus red in Crambe).

Selective settlement and survival in refuges. To investigate larval selection of microrefuges for settlement, we used experimental settlement plates that consisted of $30 \times 30 \mathrm{~cm}$ unglazed clay tiles. We offered 2 surface topographies for larval settlement: plates with a smooth surface and plates with parallel, V-shaped grooves. On the latter plates, series of 3 grooves alternated with $5 \mathrm{~mm}$ wide $\times 30 \mathrm{~mm}$-long flat areas, so that a total of $462 \mathrm{~mm}^{2}$ of the plate surface was in the form of grooves (Fig. 1). Grooves were $3 \mathrm{~mm}$ wide $\times 1 \mathrm{~mm}$ deep $\times 30 \mathrm{~mm}$ long. Apart from the pres-

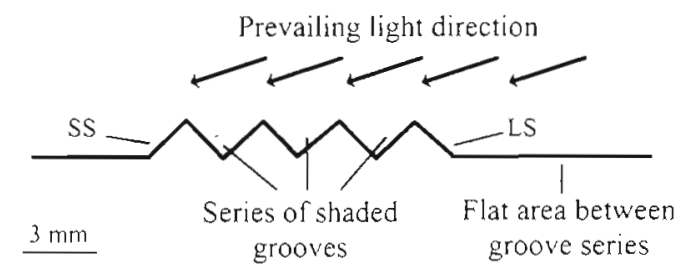

Fig. 1. Schematic illustration of the various microhabitats on a grooved plate. SS and LS indicate shaded and light-exposed sides of the 2 outer ridges of each groove series, respectively

ence/absence of grooves, the surfaces of both types of experimental plates were identical in texture and color.

A total of 10 smooth plates and 10 grooved plates were soaked in running seawater for a week, cleaned with a soft-bristled brush, taken to the field, and suspended vertically at depths of between 8 and $12 \mathrm{~m}$ from screws pre-installed at random in the rocky walls. We also determined at random whether a plate was positioned with the grooves parallel or perpendicular to the sea floor. Plate colonization by sponges was monitored in situ for $10 \mathrm{wk}$. During the period of larval release (from July 30 to September 6), plates were monitored at $3 \mathrm{~d}$ intervals; for the subsequent $5 \mathrm{wk}$ period, observations were made weekly. We counted as a settler any sponge larva that attached irreversibly to the substratum and initiated metamorphosis, regardless of its subsequent fate. We counted as recruitment any post-larval (post-metamorphic) stage that survived until censused. Because we sampled at $3 \mathrm{~d}$ intervals, actual settlement might have been underestimated. However, our previous work on these species, as well as a study by Zea (1992) reporting low levels of sponge mortality ( 0 to $12 \%$ ) over 1 to 2 d after settlement, indicated that censuses at $3 \mathrm{~d}$ intervals would provide reasonable estimates of actual settlement (see 'Discussion').

To examine larval choice for settlement site, we compared the total number of larvae that settled (irrespective of subsequent mortality) in the grooves of the grooved plates (Fig. 1) and in a similar $462 \mathrm{~mm}^{2}$ flat area on the smooth plates (Fig. 1). Differences in total settlement as a function of species (Crambe versus Scopalina) and microrefuge exploitation (grooves versus exposed sites) were analyzed by a 2 -way analysis of variance. Data on total settlement per plate were ranked prior to analysis to meet the assumption of homoscedasticity (Potvin \& Roff 1993). A posteriori comparisons were made using the Student-NewmanKeuls (SNK) test.

Post-settlement survival on the experimental plates was analyzed separately for each sponge species, because a previous 2 -factor analysis revealed that settlement was dependent on the species factor (most 
likely owing to species differences in larval supply; see 'Discussion'). In each census, we mapped all settlers in situ onto acetate sheets, so that we were able to determine if any previously settled larvae had died and how old each individual was when it djed. Then, we made a life table for each species and calculated the cumulative proportion ( $\pm \mathrm{SE}$ ) of sponges surviving up to each week interval in protected and exposed sites on the tiles (Fox 1993). Differences in survival times between individuals that were protected in the grooves of the grooved plates and exposed on the smooth plates were determined for each sponge species using the CoxMantel (CM) test (Lee 1980).

Because of the north-facing orientation of tiles in the field, the external sides of the outer ridges of each groove series received a different degree of exposure to sunlight (Fig. 1). The external side of an outer right ridge (or lower ridge, depending upon the vertical or horizontal orientation of the grooves) was always shaded (SS), whereas the external side of an outer left ridge (or upper ridge) was exposed to sunlight (LS). To test the hypothesis that microrefuges are photically located by larvae in the field, we compared total settlement in shaded versus light-exposed ridge sides on each of the 10 grooved tiles. Values of settlement on light-exposed and shaded sides of outer ridges within a given plate were paired (non-independent) observations. Therefore, differences in total settlement as a function of light exposure of the microhabitats (SS versus LS ridge sides) were determined by a $t$-test for dependent samples (Sokal \& Rohlf 1981). Differences were only assessed in Crambe, because the low number of Scopalina larvae that settled on these particular plate sites was unsuitable to support any statistical analysis.

Microrefuge protection against grazers. We tested in the laboratory the hypothesis that the herbivorous sea urchin Paracentrotus lividus and the sponge-feeding starfish Echinaster sepositus cause significant mortality among small sponges by either ingestion, abrasion, or both. We also investigated the efficiency of microrefuges for reducing sponge vulnerability to these potential predators. Experimental microrefuges consisted of grooves on the surface of $25 \times 25 \mathrm{~cm}$, unglazed clay tiles, as described in the previous section (Fig 1). We obtained small sponges by tearing tissue pieces (0.8 to $1 \mathrm{~mm}^{3}$ approximately) from large individuals of Scopalina. Once these tissue pieces are placed on an appropriate substratum within clean water, they re-attach and develop into small functional sponges (Uriz 1982). Pieces of sponge tissue were deployed on the experimental plates, which had previously been placed in plastic trays filled with $0.7 \mu \mathrm{m}$ filtered seawater. Pieces were distributed in rows of 10 pieces each, with adjacent pieces in a row $2.5 \mathrm{~cm}$ apart. To obtain sets of protected sponges, 4 rows of tissue pieces were deployed within 4 grooves, respectively, on each of the 9 grooved plates. Similarly, to obtain sets of exposed individuals, tissue pieces were arranged in 4 parallel rows on each of the smooth plates. In both cases, rows were equidistant. After $5 \mathrm{~d}$ on the plates, $93.5 \pm 0.1 \%$ (mean $\pm \mathrm{SE}$ ) of tissue pieces per row had attached and developed into small functional sponges. At this age, sponges were 1 to $2 \mathrm{~mm}^{2}$ in area, which was a size equivalent to that of an early juvenile that developed from a larva. Plates bearing small sponges were then transferred to large aquaria $\left(0.75 \mathrm{~m}^{3}\right.$ approximately) supplied with running seawater. We used a total of 9 aquaria, each containing 1 smooth plate and 1 grooved plate. We placed 5 individuals of the sea urchin $P$. lividus in each of 3 aquaria selected at random and 5 individuals of the starfish $E$. sepositus in each of 3 others. The 3 remaining aquaria contained plates with sponges but no potential predator, and served as a control. To mimic the orientation of the sponges in the field (usually growing on vertical surfaces), all plates were positioned vertically, leaning against the aquarium walls and with the side bearing the sponges towards the center of the aquarium. The position of the plates within the aquaria was changed at random at $8 \mathrm{~h}$ intervals, so that plates were leaning against different walls and sponge rows alternated between the vertical and horizontal orientation with respect to the bottom of the aquarium during the experiments. Every time we changed plate position, urchins and starfish were carefully dislodged from the aquarium walls or plates and placed in the center of the aquarium bottom. By repositioning echinoderms, we enhanced their mobility during the time of the experiment. By repositioning plates bearing sponges, we protected the experiment from potential uncontrolled effects on sponge survival owing to particular microhabitats occurring within the aquaria, such as irregular flow microconditions in some zones of aquaria and prevailing directions of pathways traced by echinoderms within aquaria. Urchins and starfish were collected from the natural community where the sponges also live, and were starved for $3 \mathrm{~d}$ to enhance foraging activity on the plates at the time of the experiment. The number of echinoderms placed in the aquaria reproduced the echinoderm density observed in the natural community 4 to 5 ind. $\mathrm{m}^{-2}$, Uriz et al. 1996).

Because both position and orientation of plates within the aquaria were periodically changed at random and the echinoderms moved erratically on the plates, we assumed for the statistical analyses that the chance of sponge mortality was independent among rows located on the same plate. We were compelled to make this assumption in the experimental design. 
because of limited running-seawater aquaria. Therefore, mortality was recorded as the percentage of sponges per row that died after $7 \mathrm{~d}$ in the experimental treatment. As some tissue pieces failed to develop into functional sponges, mortality percentages were calculated from unequal numbers of sponges per row, ranging from 6 to $10(9.3 \pm 0.1$, mean $\pm \mathrm{SE})$. Differences in sponge mortality after a week as a function of refuge exploitation (exposed vs protected sites) and the presence/absence of echinoderms (sea urchin, starfish, control) were analyzed by a 2-way analysis of variance. A posteriori pairwise comparisons were made using the SNK test.

\section{RESULTS}

\section{Selective settlement and survival in refuges}

A total of 108 Crambe larvae and 30 Scopalina larvae settled on grooved plates during the period of larval release, whereas 33 and 8 larvae, respectively, settled on smooth plates. A 2-way analysis of variance detected significant differences in total settlement per plate as a function of both sponge species and microrefuge availability, with no significant interaction between factors (Fig. 2, Table 1). A posteriori SNK tests revealed that Crambe settlers were more numerous than Scopalina settlers on the experimental plates, and that the larvae of both species settled preferentially on the grooved plates (Fig. 2).

A $B$ C D

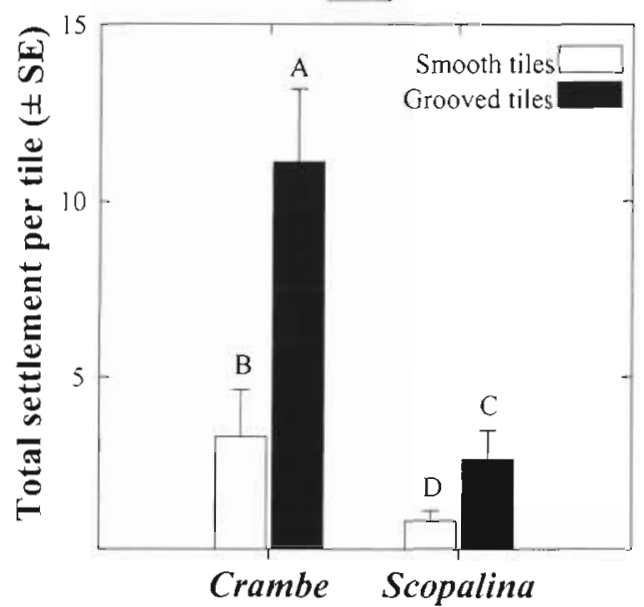

Fig. 2. Crambe crambe and Scopalina lophyropoda. Total number of larvae (mean \pm SE per plate) that settled on grooved and smooth plates over the $5 \mathrm{wk}$ period of larval release. Letters (A-D) indicate mean values arranged in descending order. Groups of underlined letters indicate nonsignificant differences in a posteriori SNK tests $(p<0.05)$ following a 2-way ANOVA based on ranked data (see Table 1)
Table 1. Two-way analysis of variance of total settlement per plate as a function of sponge species (Crambe crambe vs SCopalina lophyropoda) and plate topography (smooth versus grooved plates). See Fig. 2 for a posteriori pairwise comparisons

\begin{tabular}{|lrrrr|}
\hline Source & df & \multicolumn{1}{c}{ SS } & \multicolumn{1}{c|}{$F$} & \multicolumn{1}{c|}{ p } \\
\hline Species & 1 & 1690.0 & 24.828 & $<0.0001$ \\
Plate & 1 & 1092.0 & 16.043 & 0.0003 \\
Species $\times$ Plate & 1 & 24.0 & 0.353 & 0.5562 \\
Residual & 36 & 5256.5 & & \\
\hline
\end{tabular}

In both sponge species, settlement on the experimental plates took place for $5 \mathrm{wk}$ after plate deployment, from July 31 to September 6 (Fig. 3). After this date, no swimming larva was seen in the field and the number of recruits on the experimental plates decreased progressively for the subsequent $5 \mathrm{wk}$ (Fig. 3). The analysis of survival time (Fig. 4) revealed that the post-larval stages of both Crambe and Scopalina protected within grooves showed increased survival compared to unprotected post-larval stages (CM test statistic $=3.168, \mathrm{p}<0.001$ and $\mathrm{CM}$ test statistic $=$ $1.072, p=0.044$, respectively).

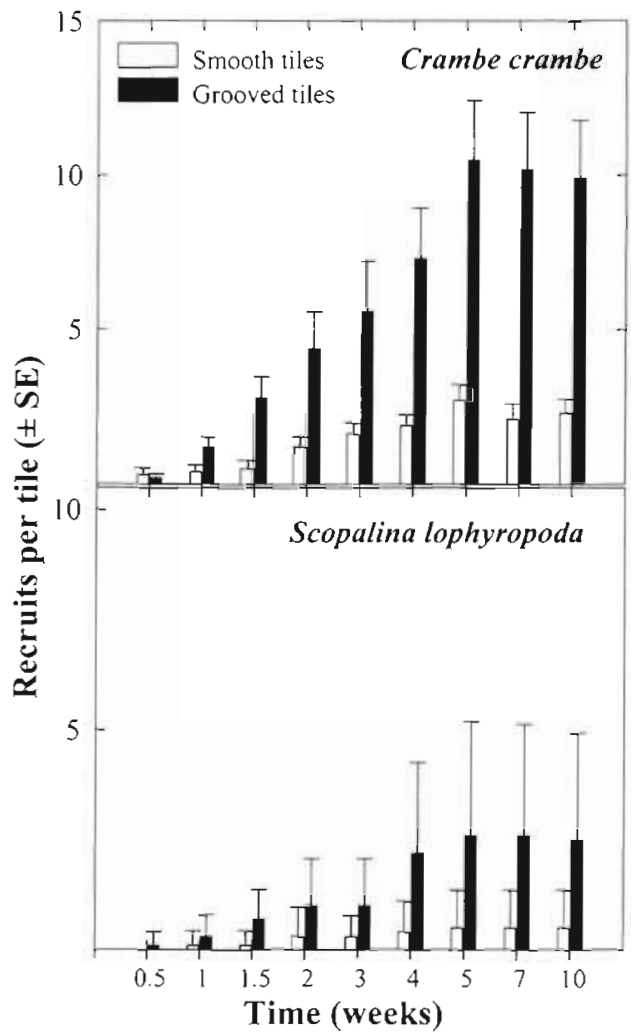

Fig. 3. Crambe crambe and Scopalina lophyropoda. Number of recruits (mean \pm SE per plate) on grooved and smooth plates over $10 \mathrm{wk}$ 


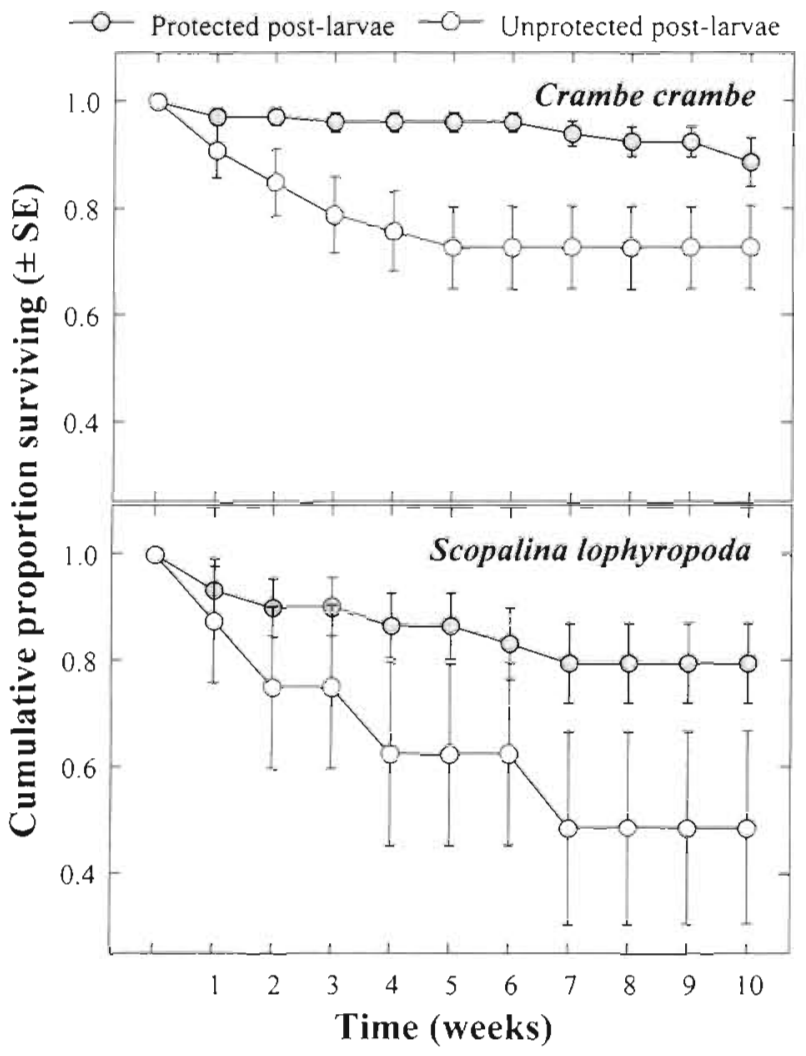

Fig. 4. Crambe crambe and Scopalina lophyropoda. Survival curves for post-larvae that settled either protected within grooves of the grooved plates or unprotected on the smooth plates

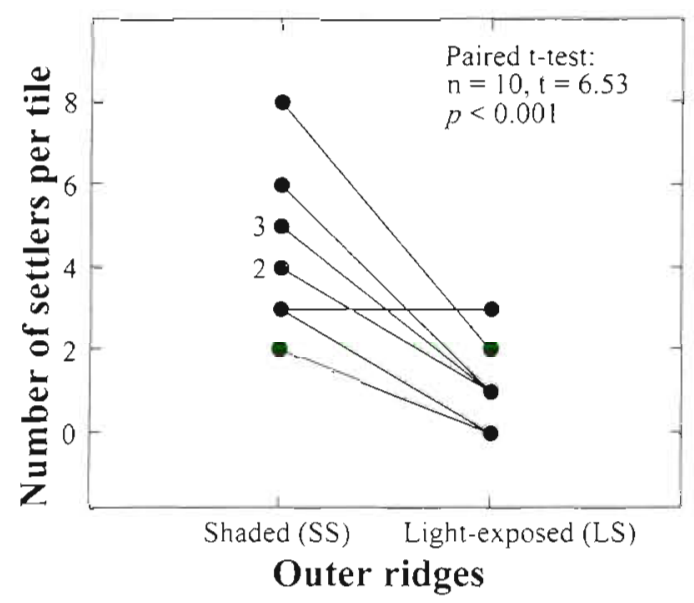

Fig. 5. Crambe crambe. Number of larvae that settled on shaded (SS) and light-exposed (LS) sides of the outer ridges of each of the 10 grooved plates. Dots joined by a line indicate paired observations within a plate. Numbers on the left hand side of dots indicate numbers of overlapping data points

On grooved plates, a total of 45 Crambe larvae settled on shaded external sides of the outer ridges (SS), whereas only 11 settled on equivalent sides highly

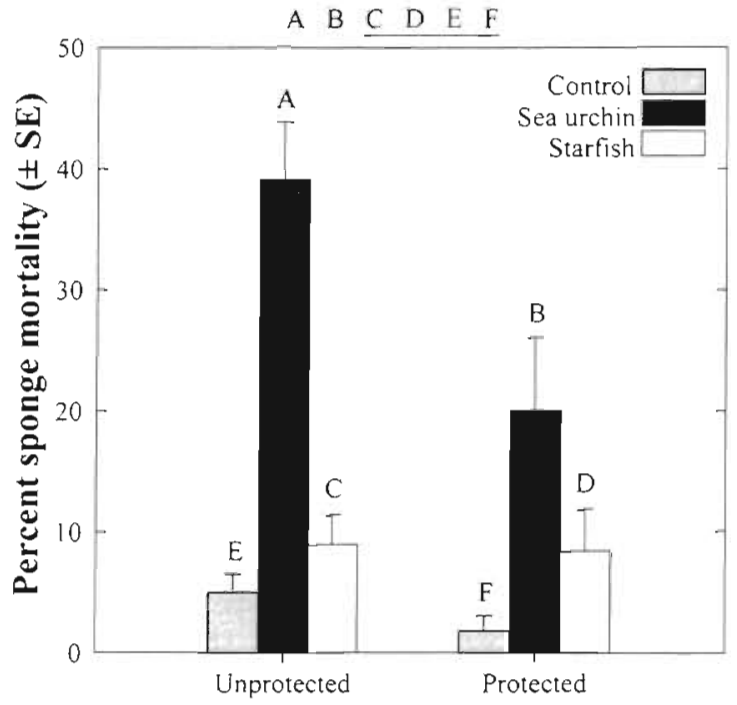

Fig. 6. Experimental mortality (\%) in Scopalina lophyropoda after $7 \mathrm{~d}$ as a function of microrefuge exploitation (sponges protected in grooves vs unprotected on smooth surfaces) and the presence of potential predators (the sea urchin Paracentrotus lividus, the starfish Echinaster sepositus, and a control with no predator in the aquaria). Letters $(A-F)$ indicate mean values arranged in descending order. Groups of underlined letters indicate non-significant differences in a posteriori SNK tests $(p<0.05)$ following a 2 -way ANOVA (see Table 2)

Table 2. Two-way analysis of variance of sponge mortality (\%) as a function of microhabitat exploitation (sponges protected in grooves vs unprotected sponges on smooth surfaces) and the presence of potential predators (Paracentrotus lividus, Echinaster sepositus, control). See Fig. 6 for a posteriori pairwise comparisons

\begin{tabular}{|lccrr|}
\hline Source & df & SS & \multicolumn{1}{c}{$F$} & \multicolumn{1}{c|}{$p$} \\
\hline Microhabitat & 1 & 0.103 & 6.50 & 0.0131 \\
Predator & 2 & 0.955 & 30.01 & $<0.0001$ \\
$\begin{array}{l}\text { Microhabitat } \times \\
\text { Predator }\end{array}$ & 2 & 0.119 & 3.75 & 0.0288 \\
Residual & 66 & 1.050 & & \\
\hline
\end{tabular}

exposed to sunlight (LS). The number of settlers on the shaded sides was significantly higher than on lightexposed sides (Fig. 5; paired $t$-tests: $t=6.53$, df $=9, \mathrm{p}<$ 0.001 ).

\section{Microrefuge protection against grazers}

A 2-way analysis of variance revealed significant differences in sponge mortality as a function of microrefuge exploitation and predator type, with a significant interaction between both factors (Table 2, Fig. 6). The significant interaction indicated that the effective- 
ness of refuges for reducing sponge mortality was dependent on the type of potential predator present in the aquaria. Subsequent 1 -way analyses of variance for the effects of predator factor within each microhabitat confirmed significant differences in mortality as a function of predator, regardless of whether the sponges were protected in grooves ( $\mathrm{df}=2, F=35.9$, $\mathrm{p}<$ 0.0001 ) or unprotected on smooth surfaces ( $\mathrm{df}=2, F=$ 5.28, $\mathrm{p}=0.010$ ). A posteriori SNK tests indicated that sponge mortality in aquaria containing the starfish Echinaster sepositus and in control aquaria was not significantly different, irrespective of microrefuge exploitation (Fig. 6). Actually, the presence of $E$. sepositus caused negligible mortality ( $<10 \%$ ). In contrast, sponge mortality was significantly higher in aquaria containing the sea urchin Paracentrotus lividus than in aquaria with the starfish or in controls, irrespective of microhabitat exploitation. The SNK test (Fig. 6) also detected that urchins caused significantly less mortality among sponges located in microrefuges $(20.9 \pm 5.9 \%)$ than among exposed individuals (39.1 \pm $4.6 \%)$.

\section{DISCUSSION}

It was predicted that encrusting sponges do not rely heavily on microrefuges or juvenile survival and, consequently, their larvae were expected to show little selectivity at the time of settlement in refuges (Walters \& Wethey 1996). In contrast, we found that larvae of both Crambe and Scopalina settled preferentially in experimental refuges and that the survival chances of the post-larval stages were increased at these sites. We also found differences in total settlement on the experimental plates as a function of sponge species. These appear to be mostly a consequence of differences in larval output between species, as supported by the fact that the number of Crambe larvae released into the water column in the community was estimated to be about 20 times higher than that of Scopalina larvae (Uriz et al. 1998).

It is unlikely that the settlement pattern we estimated by sampling at 3 d intervals was severely biased because of mortality over the first 1 to $2 \mathrm{~d}$ after settlement. Although Gosselin \& Qian (1997) have compiled a variety of studies on post-settlement mortality in benthic invertebrates and depicted a general survivorship curve that is strongly affected by high levels of firstday mortality, such a model does not appear to be appropriate for subtidal sponges. The only field study on patterns of sponge settlement and short-term recruitment reported very low mortality (0 to $12 \%$ ) among unprotected post-larval stages over the first 1 to 2 d (Zea 1992). Similarly, juveniles of the sponge Teda- nia ignis obtained in the laboratory from swimming larvae and transplanted to the field $1 \mathrm{~d}$ after settlement experienced $0 \%$ mortality within a $10 \mathrm{~d}$ period after transplantation (Maldonado 1998). We also observed the attachment process of 16 Crambe larvae and 2 Scopalina larvae during SCUBA dives for this study, and confirmed that 88.9 and $100 \%$ of those individuals respectively survived on the plates until the next $3 \mathrm{~d}$ census. Hunt \& Scheibling (1997) pointed out that the mortality rate in the field during the first few hours or days after settlement is known for only 2 groups of marine invertebrates: barnacles and ascidians. This may reduce the suitability of extrapolating the pattern inferred from this literature to other invertebrate groups. Furthermore, many of the cases reporting high first-day post-settlement mortality come from intertidal organisms (see Gosselin \& Qian 1997, Hunt \& Scheibling 1997), which are usually under particularly severe conditions and may have developed distinct survival strategies unrelated to those in subtidal environments. Therefore, our results are consistent with a variety of studies in which the mortality rate immediately after settlement was found to be similar to or just slightly higher than that of older individuals (e.g. gastropods: Underwood 1975; barnacles: Gaines \& Roughgarden 1985; ascidians: Hurlbut 1991).

Because sponge larvae are sensory-limited and are poor swimmers compared to other invertebrate larvae, it is remarkable that they are able to locate and settle selectively in the experimental microrefuges, overcoming adverse local hydrodynamic patterns. Refuges and exposed sites were not offered on the same experimental structures, but on different plates (grooved and smooth plates) that were from 1 to $25 \mathrm{~m}$ apart. Therefore, the fact that larvae settled preferentially in refuges suggests that the processes that govern the delivery of larvae to surfaces are not likely to determine where settlement occurs on a small scale (tens of centimeters). Rather, larvae appear to be able to reject the initial contact location and leave by either crawling or swimming away. This behavior was described in a previous study on Scopalina larvae (Uriz 1982) and has also been confirmed in the laboratory for larvae of both Crambe and Scopalina by using a time-lapse video camera linked to a dissecting microscope (unpubl. data). In general, the larvae of most shallow-water sponges exhibit an 'exploratory' behavior when the time of settlement approaches. This exploratory behavior lasts a variable period (from minutes to hours) depending upon the species, but it is consistently characterized by a gradual decrease in swimming speed that allows larvae to contact available substrata, crawl on them, and resume swimming if surfaces are found to be unsuitable (e.g. Bergquist \& Sinclair 1968, Bergquist et al 1970, Fell 1974, 1989, Uriz 1982, Mal- 
donado \& Young 1996). Therefore, relatively large distances may be covered and many surfaces contacted between the time of initial contact and the final attachment. There are many behavioral observations that consistently suggest that larvae are testing and searching surfaces as they crawl on the substratum, but this point remains mere speculation because no tactile or chemical receptors are known in sponge larvae to date. The behavioral panoply known in many invertebrate larvae appears to be limited in the case of sponge larvae to the ability for phototactic responses. Thus, to locate crevices or pits, sponge larvae must rely heavily on the shadow in the groove cast by its walls. Our present results on settlement on shaded versus lightexposed ridge sides indicate that microrefuges (grooves) are basically selected by the larva, at least in the case of Crambe, on the basis of photic cues. Lindquist et al. (1997) suggested that short-lived larvae of shallow-water sponges that require photic cues to select settlement sites should be released in the morning to increase the chances for the larvae to choose a suitable shaded spot. This prediction is consistent with the pattern observed in the 2 species studied, in which massive larval releases have always been detected in the field during the morning of sunny days with calm sea.

The fact that post-settlement survival of both sponge species was enhanced in microrefuges suggests that the ability of larvae to find and settle preferentially at these sites has developed under selective pressure. Very little is known about the causes of post-settlement mortality in the field. Most observations on this issue come from tropical areas where a large variety of common fish prey more or less selectively on sponges (Randall \& Hartman 1968, Wulff 1994), so that causes and patterns of juvenile sponge mortality in tropical environments cannot easily be extrapolated to temperate sponge assemblages, in which this factor of mortality is negligible (Sará \& Vacelet 1973). In temperate subtidal regions, bulldozing by sea urchins is a major cause of juvenile mortality, especially on hard substrata (Ebert 1977, Karlson 1978, Vance 1979. Ayling 1980, 1981, Sammarco 1980). Our laboratory experiment indicates that abrasion and/or unselective ingestion by the urchin Paracentrotus lividus causes significant mortality among small sponges and that exploitation of crevices and similar refuges reduces sponge vulnerability to this cause of mortality. The presence of grazing tracks on our experimental plates in the field was usually associated with loss of juvenile sponges in or near the track. These results and observations are also consistent with a variety of studies reporting that accidental ingestion or bulldozing by grazers such as limpets, littorinids and sea urchins causes mortality among newly settled barnacles, limpets, ascidians and corals (Dayton 1971, Sammarco 1980, Petraitis 1983, Young \& Chia 1984, Prince 1995). Similarly, substratum heterogeneity has also been shown to protect early post-larval stages and reduce vulnerability to this cause of mortality in corals (Sammarco 1980), barnacles (Connell 1961, Dayton 1971, Miller \& Carefoot 1989) and bivalves (Menge \& Lubchenco 1981). No sponge outgrew the experimental refuges during our $10 \mathrm{wk}$ study, so we could not assess whether or not there is a change in the effectiveness of the refuges assayed with increasing sponge size. We found that the starfish Echinaster sepositus, which is regarded as a sponge-feeding generalist (Vasserot 1961, Sará \& Vacelet 1973, García-Raso et al. 1992), did not cause significant sponge mortality, unlike urchins. This unexpected result made it evident that our knowledge of the causes of mortality among juvenile sponges is very limited. There are probably many other mortality factors that may be important in the field, but remain absolutely unexplored so far. For example, during an unrelated experiment in which sponges that had settled on artificial panels in the laboratory were transplanted to the field, we observed how an octopod (Octopus vulgaris) explored a panel by tentacle touching and removed 55 out of 60 newly settled sponges in just $10 \mathrm{~min}$ after panel deployment. Obviously, tentacle touching on the panel surface was unnaturally enhanced by the animal's curiosity in the presence of a new, unusual object in its territory. The extent to which this type of unpredictable factor may have affected other field experiments and operates as a natural cause of juvenile mortality remains unknown.

The present study shows that the parenchymella larvae of 2 subtidal sponges are able to locate and settle preferentially within experimental microrefuges in field conditions. This larval ability has probably evolved under selective pressure, since early post-settlement survival was found to be significantly enhanced at preferred settlement sites. Our results also suggest that bulldozing by sea urchins may be a major cause of mortality among juvenile sponges in temperate hard-bottom communities where sea urchins are abundant, and that physical microrefuges (in the sizc assayed) are efficient at reducing vulnerability to this cause of mortality. However, more studies on settlement and juvenile sponge mortality should be undertaken to gain understanding on this critical period and its potential effects on subsequent life-history stages.

Acknowledgements. We thank E. Bravo, M. C. Carmona, R. Martí and $M$. Bardaji for help in field and laboratory tasks. This research was supported by 2 grants (DGCYT: PB-940015-C02-01, CICYT: MAR95-1764\} and funds of the Generalitat de Catalunya (1997SGR00084). 


\section{LITERATURE CITED}

Amano S (1986) Larval release in response to a light signal by the intertidal sponge Halichondria panicea. Biol Bull 171. $371-378$

Ayling AL (1980) Patterns of sexuality, asexual reproduction and recruitment in some subtidal marine Demospongiae. Biol Bull 158:271-282

Ayling AM (1981) The role of biological disturbance in temperate subtidal encrusting communities. Ecology 62: 830-847

Ballesteros E (1987) Distribución de Paracentrotus lividus (L.M.K.) y Arbacia Lixula (L.) (Echinodermata, Echinoidea) en la zona infralitoral de la Costa Brava. Cuad Marisq Publ Téc 11:225-232

Barry JP, Dayton PK (1991) Physical heterogeneity and the organization of marine communities. In: Kolasa J, Pickett STA (eds) Ecological heterogeneity. Springer-Verlag, New York, p 270-320

Becerro MA, Uriz MJ, Turon X (1994) Trends in space occupation by the encrusting sponge Crambe crambe: variation in shape as a function of size and environment. Mar Biol 121:301-307

Bergquist PR, Sinclair ME (1968) The morphology and behaviour of larvae of some intertidal sponges. NZ J Mar Freshwat Res 2:426-437

Bergquist PR, Sinclair ME, Hogg JJ (1970) Adaptation to intertidal existence: reproductive cycles and larval behaviour in Demospongiae. Symp Zool Soc Lond 25:247-271

Chabot R, Bourget E (1988) Influence of substratum heterogeneity and settled bamacle density on the settlement of cypris larvae. Mar Biol 97:45-56

Connell JH (1961) Effects of competition, predation by Thais lapillus and other factors on natural populations of the barnacle Balanus balanoides. Ecol Monogr 31:61-104

Dance C (1987) Patterns of activity of the sea urchin Paracentrotus lividus in the bay of Port-Cros (Var, France, Mediterranean). PSZN I: Mar Ecol 8:131-142

Dayton PK (1971) Competition, disturbance, and community organization: the provision and subsequent utilization of space in a rocky intertidal community. Ecol Monogr 41:351-389

Dayton PK (1989) Interdecadal variation in an Antarctic sponge and its predator from oceanographic climate shifts. Science 245:1484-1486

Ebert TA (1977) An experimental analysis of sea urchin dynamics and community interactions on a rock jetty. J Exp Mar Biol Ecol 27:1-22

Fell PE (1974) Porifera. In: Giese AC, Pearse JS (eds) Acoelomate and pseudocoelomate metazoans. Academic Press, New York, p 51-132

Fell PE (1989) Porifera. In: Adiyodi KG, Adiyodi RG (eds) Reproductive biology of invertebrates, Vol IV, Part A, Fertilization, development and parental care. John Wiley \& Sons, New York, p 1-41

Fox GA (1993) Failure-time analysis: emergence, flowering, survivorship, and other waiting times. In: Scheiner SM, Gurevitch $J$ (eds) Design and analysis of ecological experiments. Chapman \& Hall, New York, p 253-289

Gaines SD, Roughgarden J (1985) Larval settlement rate: a leading determinant of structure in an ecological community of the marine intertidal zone. Proc Natl Acad Sci USA 82:3707-3711

García-Raso E, Luque AA, Templado J, Salas C, Hergueta E, Moreno D. Calvo M (1992) Fauna y flora marina del parque natural de Cabo de Gata-Nijar. Junta de Andalucía, Madrid

Gosselin LA, Qian PY (1997) Juvenile mortality in benthic marine invertebrates. Mar Ecol Prog Ser 146:265-282

Hunt HL, Scheibling RE (1997) Role of early post-settlement mortality in recruitment of benthic marine invertebrates. Mar Ecol Prog Ser 155:269-301

Hurlbut CJ (1991) Community recruitment: settlement and juvenile survival of seven co-occurring species of sessile marine invertebrates. Mar Biol 109:507-515

Hurlbut CJ (1993) The adaptive value of larval behavior of a colonial ascidian. Mar Biol 115:253-262

Jackson JBC (1977) Competition on marine hard substrata: the adaptive significance of solitary and colonial strategies. Am Nat 111:743-767

Jackson JBC, Hughes TP (1985) Adaptive strategies of coral reef invertebrates. Am Sci 73:265-274

Karlson R (1978) Predation and space utilization patterns in a marine epifaunal community. J Exp Mar Biol Ecol 31: $225-239$

Keough MJ, Downes BJ (1982) Recruitment of marine invertebrates: the role of active larval choices and early mortality. Oecologia 54:348-352

Krasko A, Müller IM, Müller WEG (1997) Evolutionary relationships of the metazoan $\beta \gamma$-crystallins, including that from the marine sponge Geodia cydonium. Proc R Soc Lond B 264:1077-1084

Lee ET (1980) Statistical methods for survival data analysis. Lifetime learning, Belmont, CA

Lindquist N, Bolser R, Laing K (1997) Timing of larval release by two Caribbean demosponges. Mar Ecol Prog Ser 155: 309-313

Maldonado $M$ (1998) Do chimeric sponges have improved chances of survival? Mar Ecol Prog Ser 164:301-306

Maldonado M, George SB, Young CM, Vaquerizo I (1997) Depth regulation in parenchymella larvae of a demosponge: relative roles of skeletogenesis, biochemical changes and behavior. Mar Ecol Prog Ser 148:115-124

Maldonado M, Young CM (1996) Effects of physical factors on larval behavior, settlement and recruitmet of four tropical demosponges. Mar Ecol Prog Ser 138:169-180

McDougall KD (1943) Sessile marine invertebrates of Beaufort, N.C. Ecol Monogr 13:321-374

Menge BA, Lubchenco J (1981) Community organization in temperate and tropical rocky intertidal habitats: prey refuges in relation to consumer pressure gradients. Ecol Monogr 51:429-450

Miller KM, Carefoot TH (1989) The role of spatial and size refuges in the interactions between juvenile barnacles and grazing limpets. J Exp Mar Biol Ecol 134:157-174

Nédeléc H (1982) Ethologie alimentaire de Paracentrotus lividus dans la Baie de Galéria (Corse) et son impact sur les peuplements phytobentiques. PhD thesis, Univ Pierre et Marie Curie

Petraitis PS (1983) Grazing patterns of the periwinkle and their effects on sessile intertidal organisms. Ecology 64: $522-533$

Potvin C, Roff DA (1993) Distribution-free and robust statistical methods: viable alternatives to parametric statistics? Ecology 74(6):1617-1628

Prince J (1995) Limited effects of the sea urchin Echinometra mathaei (de Blainville) on the recruitment of benthic algae and macro invertebrates into intertidal rock platforms at Rottnest Island, Western Australia. J Exp Mar Biol Ecol $186: 237-258$

Randall JE, Hartman WD (1968) Sponge-feeding fishes of the West Indies. Mar Biol 1:216-225

Sammarco PW (1980) Diadema and its relationship to coral spat mortality: grazing, competition, and biological disturbance. J Exp Mar Biol Ecol 45:245-272 
Sará M, Vacelet J (1973) Ecologie des Démosponges. In Grassé PP (ed) Spongiaires. Anatomie, physiologie, systématique, ecologie. Masson et Cie, Paris, p 462-576

Shepherd SA, Boudouresque CF (1979) A preliminary note on the movement of the sea urchin Paracentrotus lividus. Trav Scient Parc Natn Port-Cros 5: 155-158

Sokal RR, Rohlf FJ (1981) Biometry. WH Freeman, San Francisco

Turon X, Becerro MA, Uriz MJ, Llopis J (1996) Small-scale association measures in epibenthic communities as a clue for allelochemical interactions. Oecologia 108:351-360

Turon X, Giribet G, López S, Palacín C (1995) Growth and population structure of Paracentrotus lividus (Echinodermata: Echinoidea) in two contrasting habitats. Mar Ecol Prog Ser 122:193-204

Underwood AJ (1975) Comparative studies on the biology of Nerita atramentosa Reeve, Bembicium nanum (Lamarck) and Cellana tramoserica (Sowerby) (Gastropoda: Prosobranchial in S.E. Australia. J Exp Mar Biol Ecol 18: $153-172$

Uriz MJ (1982) Morfología y comportamiento de la larva parenquimula de Scopalina lophyropoda Schmidt 1862 (Demospongia, Halichondrida) y formación del rhagon. Invest Pesq 42:313-322

Uriz MJ, Maldonado M, Turon X, Martí R (1998) How do reproductive output, larval behaviour, and recruitment contribute to adult spatial patterns in Mediterranean encrusting sponges? Mar Ecol Prog Ser 167:137-148

Uriz MJ, Turon X, Becerro M, Galera J (1996) Feeding deterrence in sponges. The role of toxicity, physical defenses, energetic contents, and lite-history stage. J Exp Mar Biol Ecol 205:187-204

Editorial responsibility: Otto Kinne (Editor),

Oldendorf/Luhe, Germany
Vance RR (1979) Effects of grazing by the sea urchin Centrostephanus coronatus on prey community composition Ecology 60:537-546

Vasserot J (1961) Caractère hautement spécialisé du régime alimentaire chez les Asterides Echinaster sepositus et Henricia sanguinolenta, prédateurs de Spongiaires. Bull Soc Zool Fr 86:796-809

Walters LJ (1992) Field settlement locations on subtidal marine hard substrata: is active larval exploration involved? Limnol Oceanogr 37:1101-1107

Walters LJ, Wethey DS (1996) Settlement and early post-settlement survival of sessile marine invertebrates on topographically complex surfaces: the importance of refuge dimensions and adult morphology. Mar Ecol Prog Ser 137: $161-171$

Woollacott R (1993) Structure and swimming behavior of the larva of Haliclona tubifera (Porifera: Demospongiae). J Morphol 218:301-321

Wulff JL (1994) Sponge feeding by Caribbean angelfishes, trunkfishes, and filefishes. In: Van Soest RMW, van Kempen TMG, Braekman JC (eds) Sponges in time and space. AA. Balkema, Rotterdam, p 265-271

Wulff JL (1995) Effects of a hurricane on survival and orientation of large erect coral reef sponges. Coral Reefs 14: $55-61$

Young CM, Chia FS (1984) Microhabitat-associated variability in survival and growth of subtidal solitary ascidians during the first 21 days after settlement. Mar Biol 81:61-68

Zea S (1992) Estimation of demosponge (Porifera, Demospongiae) larval settlement rates from short-term recruitment rates: preliminary experiments. Helgoländer Meeresunters 46:293-300

Submitted: April 29, 1998; Accepted: August 21, 1998

Proofs received from author(s): October 26, 1998 